\title{
The Author's "Psychological Autobiography"-"Martin Eden" Is an Autobiographical Novel of Appreciation
}

\author{
Siqi Wang \\ Minzu University of China, Sichuan, Ziyang \\ email
}

Keywords: Psychology; Martin Eden; Autobiographical Novels

\begin{abstract}
Martin Eden, as a realistic autobiographical novel, is of great significance in the history of American literary creation. The author, in the creation of Martin Eden, at the same time puts his own life, emotional experience and psychological growth process into showing a realist obvious heroin a three-dimensional way. This paper analyzes the author Jack London's psychological mapping in his novels from three aspects: work experience, emotional life and influence of external thought. The protagonist's idealistic fantasy of love and life finally goes to disillusionment, which is the intrinsic motivation of his mental state change. Although Martin Eden has acquired a positive mental form in the process of meeting the needs, at last, the failure of self-actualization needs leads to the extreme of life, and to achieve physical and psychological relief through suicide.
\end{abstract}

\section{Introduction}

Martin Eden is a famous work of American realist writer Jack London. The author adopts the form of autobiographical novel, which is based on his own life, emotional experience and psychological characteristics, and succeeds in shaping the character of Martin Eden. The whole work has achieved great achievements in both thought and art. The author describes Martin Eden's legendary and tragic life through the exquisite psychological description and the description of the language, and also reflects the hypocrisy of bourgeois civilization. The protagonist, from the yearning for love, life, until the real disappointment at the capitalist society, the change of psychological state is also the author's own real reflection with the reality of American society at that time. Martin Eden's ultimate self-destruction was the end of his ideal.

\section{The Author's Psychological Growth Fits the Novel of Martin Eden}

\subsection{The Author's Work and Life Environment}

Jack London's complex life experience reflected in the novel of Martin Eden, which embodies the leading character's unyielding character which gradually grows up. Jack London has experienced a hard life since he was a child. A good stepfather cannot rely on low income to support family expenses. Without any choice, Jack London has been engaged in laundry workers, sailors and other hard work. The whole family had a difficult life. It is gratifying that the stepfather and his daughter Elizabeth take care of Jack London well. In addition, Jack London has also been to Mexico, Japan and many other countries in the world.

The author's experience has reflected in the novel of Martin Eden. Jack London and his sister depend on each other after his father and mother died, also engaged in sailors, workers and other hard work, relying on work to make a living for themselves. Actually, his life is extremely difficult. There is a large narrative in the novel about Martin Eden travels all over the world. Therefore, Martin Eden's increasingly strong psychological through the hard life, is also the true reflection of the author's Mental state. 


\subsection{The Author's Emotional Life Experience}

Martin Eden and Ruth's love in the novel is the author and his first love Mabel Applegarth's love in the real life. In the real life, Mabel was born in a wealthy family but Jack London had a difficult life, a union between them would be impossible. Their love was opposed by Mabel's mother. Over a period of years, John's success will come, but just before it does, Mabel broke up with him under the pressure of the family. In the London, his emotional life also involves three other women, respectively, two wives and his stepfather's daughter. In the novel of Martin Eden, the leading character and Ruth's love corresponds to the Jack London and Mabel's love story. At the same time, his sister, as well as Lizzie Connolly, Margey is also an important part of the emotional life of the leading character. Therefore, Jack London and Martin Eden is the same in the emotional life. It means that when the author wrote this novel, he incorporates his own emotional experience.

\subsection{The External Thought Accepted by the Author}

Jack London was influenced by a variety of external thoughts, mainly including literary thought of Balzac and Shakespeare, the philosophy of Spencer and Marx and the socialist political thought. Among the various external philosophical thought, view of death of Nietzsche is the most memorable for Jack London. Concepts of "Dearth must be transcended to attain freedom of will" and "One person's death is the source of human circulation" most impress Jack London's psychology and result in the suicide of London and Martin. After further acquaintance of the works of Jack London, it can be seen that the ideas and theories of Darwin and Spencer are the leading factors of his style. In the novel Martin Eden, the life and writing of the protagonist are both judged by Spencer's theory which is also seen as a binding force of daily behavior. Even the association with Ruth is rich with Spencer's theory. Hence we can see that the author endows his own external thought to the psychological characteristics of Martin Eden.

\section{Spiritual Change Course of Martin Eden}

\subsection{Emotional Pessimism after the Loss of Love}

Humans are eager for a perfect love deep down for the needs of human physiological instinct. This psychological appeal is also reflected in Jack London and Martin Eden. In the novel Martin Eden, the protagonist did not create emotional response to women from the bottom of society like him, but fell in love with Ruth from the high-level bourgeois. This indicates that the pursuit of excellent opposite sex accords with the psychological instinct of human. Although the love between them is opposed by family members of Ruth, Martin still regards it as the power to support his efforts to write. In order to make up for and narrow the difference of class life between Ruth and him, Martin Eden learns English, tries to write and gets rid of his lifestyle.

It is no other than the obsession of the perfect love that makes him falls into a circle of emotional pessimism. Martin loves more his own fantasy of a beauty than Ruth. She did not understand, encourage and support Martin from her heart. She would prefer Martin to enter the bourgeois life and bring her the rich life. She even abandoned him at the worst period of his writing. Martin Eden also gradually realized that his desire for love is only fantasy and Ruth wasn't as good as he thought. As the two persons got along slowly, Martin was even disgusted with Ruth and the upper society. The great contrast between the inner instinct of love and the reality of emotional life becomes one of the important reasons of the distorted psychology of Martin Eden.

\subsection{Mental Distortion after the Collapse of the Wish for a Better Life}

Martin Eden's wish for a better life begins from the evening dinner at Ruth Morse's family. Martin showed his disappointment over his life condition defined as the bottom of society. He starts to hate his destitute life being a sailor and even hate to see his elder sisters' life style. He began to consciously leave his current social circle and tried to fit in the bourgeoisie circle. Under the support of love, Martin eagered to achieve the life style shift through writing. Although this is extremely difficult, Martin started to learn English from scratch, and constantly polished his literary 
ability, and ultimately grew into an outstanding literary master. His life has also undergone a significant change and obtained plenty of wealth. Martin's positive attitude toward career and life reflects his psychological positive emotions.

However, Martin who realized the freedom of wealth did not get the long-awaited life state. After entering the upper bourgeois society, he regretted that the life was not his own imagination and no happiness has been enjoyed from the rich life. Hence he tried to return to the bottom of society, hoping to find his old friends. However, after several attempts, Martin found that it was far more difficult to go back into his old life. Not only has he had difficulty in adapting into the underclass environment, but also living together with his old friends. The floating life in between the upper and lower levels of society made Martin Eden fall into a passive state of loneliness and sense of crisis, and ultimately he chose to end the psychological fear through suicide.

\section{The Interpretation of Humanistic Psychological Characteristics in Martin Eden}

\subsection{Make Unremitting Efforts for Satisfying Deficiency Need}

According to American psychologist Maslow's hierarchy of needs, human needs can be divided into deficit needs and need for self-actualization. Deficit needs involve physiological needs, safety needs, love and belonging needs and esteem needs. As the basis of need for self-actualization, deficit needs are directly related to the basic existing form of individual life. Martin Eden was born in a poor family and thus he would meet deficit needs primarily. In order to meet physiological needs and slove subsistence problem, he has engaged in various jobs. After the efforts to satisfy safety needs, his adoration to Lucy and help offered to his friends reflect love and belonging needs. Martin works hard as a writer and attempts to enter upper class so as to close the class gap between Lucy and himself, which reflects his esteem needs. Finally he becomes a master in literature through his persistent endeavor.

Therefore, we could draw a conclusion that Martin is in a positive mood during the process of satisfying deficit needs. He grows from a low-income and shabby sailor to a literary master and climbs to upper class, during which he achieves physiological needs, safety needs, love and belonging needs and esteem needs step by step. Driven by deficit needs, Martin's positive attitude plays a leading role in this process.

\subsection{Disappointment of Self-Fulfilling Demand}

As the top of Maslow's theory of demand pyramid, self-fulfilling demand is the psychological motive that individuals will inevitably produce when the deficiency need is satisfied. It includes not only the realization of personal values and ambition, but also the maximization of individual ability, EQ and IQ. In the book Martin Eden, the protagonist's self-fulfilling demand comes from his longing for a better life and perfect love, in the support of this, Martin showed extraordinary enthusiasm for his work. As described in the novel, he can continuously work for 40 hours without any interruption, or just sleep for 5 hours a day in order to become successful as soon as possible as a great writer. He works that hard because he believes his hard working will lead him to an ideal life and meet his self-fulfilling demand, which, though, eventually failed.

After Martin lost his love with Ruth, his attitudes toward the upper class also changed, which leads to the fall-apart of the foundation of his self-fulfilling demand and the failure eventually. At the end of Martin's relationship with Ruth, he found that they did not love each other, Ruth is still pursuing the material well-being life of the upper class, and she is not the perfect lover in his love fantasy. The situation is the same when it comes to his illusion for the life of the upper class, when Martin found that his happiness did not come from the material things, and the life of the lower class had left him forever, he realized that it was impossible for him to achieve the self-fulfilling demand. Being aware of this, Martin was extremely disappointed, that's why he finally committed suicide, so that his body and soul could return to the very origin. 


\section{Conclusion}

The autobiographical novel Martin Eden not only depicts Martin Eden as an unyielding man with a vivid and realistic description of his legendary and tragic life, but also reflects the author's own mental form and his hatred for the hypocrisy of American capitalist society. Martin Eden's psychological changes are analyzed from the angle of Maslow's demand theory, although the hero made unremitting efforts on the road from deficiency need to self - fulfilling demand, it's still a road to destruction. All this is derived from the gap between protagonist's desire for a better life and the dark reality of the capitalist society. We can read Jack London's self-expression in the book and can also see his accusation of the inhuman life in the capitalist society.

\section{References}

[1] Li Xiaofan. Discover the Tragedy of Jack London's Life from Martin Eden [J]. Journal of Hubei University of Science and Technology, 2015,35(03):58-60.

[2] Shen Lifeng. Ethical Dilemmas and Ethical Choices in Martin Eden [J]. Foreign Literature Studies,2015,37(03):87-94.

[3] Deng Yanlin. The Tragedy of the Striver- Psychological Interpretation of Martin Eden [J]. Journal of Heilongjiang College of Education, 2015,34(11):124-126.

[4] Duan Hongyu, Duan Hongyan. On the Writing of Cultural Politics in Jack London's Anti-Initiation Novel Martin Eden [J]. Journal of Northeast Normal University (Philosophy and Social Sciences),2014, (03):132-137.

[5] Song Ying. The Similarities between Jack London and Martin Eden [J]. Journal of Dalian Maritime University (Social Sciences Edition),2014,13(03):105-108. 